\title{
A Case Study of Analyzing Emotional Exhaustion from A Medical Center in Taiwan
}

\author{
(Studi Kasus Kelelahan Emosional Karyawan Sebuah Pusat Medis di Taiwan)
}

\author{
Yii-Ching Lee ${ }^{1,2}$, Chih-Hsuan Huang ${ }^{3,4}$, Diniy Hidayatur Rahman ${ }^{5}$ Chia-Hui Yu ${ }^{6,7}$, Hsin-Hung \\ $\mathrm{Wu}^{8,9 *}$ \\ ${ }^{1}$ Department of Health Business Administration, Hung Kuang University, \\ No. 1018, Sec. 6, Taiwan Boulevard, Shalu District, Taichung City, 43301 Taiwan \\ ${ }^{2}$ Ben Tang Cheng Ching Hospital, No. 718, Zhongzheng Road, Wufeng District, Taichung City, 41341 Taiwan \\ ${ }^{3}$ School of Business Administration, Hubei University of Economics, \\ No. 8, Yangqiaohu, Jiangxia District, Wuhan, 430205 China \\ ${ }^{4}$ Institute for Development of Cross-Strait Small and Medium Enterprise, Hubei University of Economics, \\ No. 8, Yangqiaohu, Jiangxia District, Wuhan, 430205 China \\ ${ }^{5}$ Department of Guidance and Counseling, Faculty of Education, Universitas Negeri Malang, \\ Semarang Street. No 5. Malang, East Java, 65145 Indonesia \\ ${ }^{6}$ College of Nursing, Chung Shan Medical University, \\ No. 110, Section 1, Jianguo North Road, South District, Taichung City, 40201 Taiwan \\ ${ }^{7}$ Mass Communication Center, Chung Shan Medical University Hospital, \\ No. 110, Section 1, Jianguo North Road, South District, Taichung City, 40201 Taiwan \\ ${ }^{8}$ Department of Business Administration, College of Management, National Changhua University of Education, \\ No. 1, Jinde Road, Changhua City, Changhua County, 50007 Taiwan \\ ${ }^{9}$ Department of M-Commerce and Multimedia Applications, Asia University \\ No.500, Liufeng Road, Wufeng District, Taichung City, 40001 Taiwan \\ *corresponding author, e-mail: hhwu@cc.ncue.edu.tw
}

Article received: November $6^{\text {th }} 2019$; revised: November $18^{\text {th }} 2019$; accepted: December $1^{\text {st }} 2019$

\begin{abstract}
This study uses a medical center in Taiwan as an example to analyze medical staff's emotional exhaustion by independent sample $t$ test and analysis of variance. Eight out of ten demographic variables are considered as essential variables to influence emotional exhaustion excluding respondents reporting events in the past 12 months and job status. The results show that female employees and employees who are not supervisors/managers tend to have higher burnout. Employees whose ages are 21-30, $31-40$, and 41-50 years old also have a higher degree of fatigue. In addition, nurses are more stressful than the others in this medical center. The detailed post hoc analyses enable hospital management to identify employees with high burnout. Finally, this study also provides some recommendations to help hospital management reduce employees' burnout.
\end{abstract}

Keywords: emotional exhaustion; safety attitudes questionnaire; medical center; independent sample $\mathrm{t}$ test; analysis of variance

\begin{abstract}
Abstrak: Penelitian ini bertujuan untuk menganalisis kelelahan emosional para staf di sebuah pusat medis di Taiwan. Analisis data dilakukan dengan uji $\mathrm{t}$ (sampel independen) dan analisis variansi. Hasil analisis menunjukkan bahwa delapan dari sepuluh variabel demografis merupakan variabel yang berpengaruh pada kelelahan emosional para subjek. Lebih lanjut, ditemukan bahwa staf medis perempuan dan staf yang tidak berposisi sebagai supervisor/manajer cenderung mengalami burnout yang lebih tinggi. Staf yang berusia 21-30, 31-40, dan 41-50 tahun juga memiliki tingkat kelelahan emosional yang lebih tinggi. Selain itu, para perawat mengalami stres yang lebih tinggi dibandingkan dengan staf lainnya. Analisis post hoc secara detail dalam penelitian ini memberikan informasi tentang staf-staf yang mengalami burnout tingkat tinggi. Berdasarkan hasil tersebut, beberapa saran diajukan pada manajemen pusat medis dimaksud untuk meningkatkan ketahanan staf-stafnya terhadap burnout.
\end{abstract}

Kata kunci: kelelahan emosional; safety attitudes questionnaire; pusat medis; uji t sampel independen; analisis variansi

$\overline{\text { How to cite: Lee, Y. C., Huang, C. H., Rahman, D. H., Yu, C. H., \& Wu, H. H. (2020). A Case Study of Analyzing Emotional Exhaustion from A Medical }}$ Center in Taiwan. Jurnal Kajian Bimbingan dan Konseling, 5(1), 1-8. https://doi.org/10.17977/um001v5i12020p001 


\section{INTRODUCTION}

Burnout is a prolonged response to chronic emotional and interpersonal stressors on the job and to treat people as if they were objects and have sense that the work is no longer meaningful (Maslach et al., 2001; Shanafelt, 2009). Burnout impairs both personal and social functioning and reduces the work quality and health both physically and psychologically (Maslach et al., 2016). The burnout syndrome affects each individual worker in all fields including people interacting with that particular worker (Shanafelt et al., 2017). Studies have shown that burnout would have negative impacts on healthcare workers. For instance, physicians' burnout increases medical errors and decreases patient care (Shanafelt et al., 2010; West et al., 2016). Besides, nurses' burnout increases infection rates and decreases patient healthcare quality (Cimiotti et al., 2012).

Huang et al., (2019) stated that providing good medical services is important to a sustainable development of healthcare organizations in a highly competitive healthcare industry. Understanding the medical staff's attitudes about patient safety particularly emotional exhaustion (EE) is important to enhance the patient safety culture and reduce the medical errors when the medical staff with high burnout are found (Huang, et al., 2018; Huang, Wu, et al., 2018). That is, medical staff with a higher degree of burnout have negative effects on patient safety and healthcare quality (Lee, Huang, Huang, et al., 2016).

The Joint Commission of Taiwan borrowed emotional exhaustion from Maslach burnout inventoryhuman services survey (MBI-HSS) with three dimensions to form a new version of the safety attitudes questionnaire (SAQ) to assess the patient safety culture from viewpoints of medical staff annually for each healthcare in Taiwan since 2014 (Chi et al., 2019; Lee et al., 2017). EE is defined as workers who are unable to perform their jobs at a psychological level as emotional resources are depleted (Lee, Huang, Weng, et al., 2016; Maslach et al., 2001). Lee, Huang, Weng, et al., (2016) summarized that different physicians and nurses perceive emotional exhaustion differently. Chi et al., (2019) also identified employees with different demographic variables perceive EE differently. Therefore, it would be of interest to observe how medical staff perceive in emotional exhaustion.

A case study of a medical center located in Taichung City, Taiwan is presented to study how different employees perceive burnout in terms of EE dimension based on the Chinese version of the SAQ. In doing so, hospital management can identify the medical staff who perceive a higher degree of burnout and then reduce the burden to provide better healthcare quality and enhance patient safety (Lee, Huang, Huang, et al., 2016).

\section{METHOD}

Emotional exhaustion has nine questions as shown in Table 1. (Lee et al., 2017). Each medical staff is asked to answer every question by a Likert's scale with five levels, namely strongly agree to strongly disagree with the respective values of 5 to 1 . It is worth to note that each question is negative wordings. That is, the smaller value indicates lower burnout. Moreover, the score of emotional exhaustion is to sum up the scores from these nine questions. That is, the score range in EE dimension is 9 to 45 .

Table 1. Descriptions of Emotional Exhaustion

\begin{tabular}{ll}
\hline \multicolumn{1}{c}{ Dimension } & \multicolumn{1}{c}{ Question } \\
\hline Emotional & 1. I feel like I'm at the end of my rope. \\
Exhaustion & 2. I feel burned out from my work. \\
& 3. I feel frustrated by my job. \\
& 4. I feel I'm working too hard on my job. \\
& 5. I feel emotionally drained from my work. \\
& 6. I feel used up at the end of the workday. \\
& 7. I feel fatigued when I get up in the morning and have to face another day on the job. \\
& 8. Working with people all day is really a strain for me. \\
9. Working with people directly puts too much stress on me.
\end{tabular}


The purpose of this study is to observe if medical staff with different demographic variables from a medical center in Taiwan have different perceptions statistically in EE from the SAQ internal surveyed data conducted by this case medical center in 2017. The effective number of questionnaires is 1534 . To analyze if medical staff perceive EE differently in terms of demographic variables, independent sample $\mathrm{t}$ test and analysis of variance (ANOVA) with $\alpha=0.05$ are applied to nine questions of emotional exhaustion dimension. Bonferroni method is applied for post hoc analysis excluding gender and supervisor/manager because McHugh, (2011) concluded that Bonferroni method outperforms Scheffe method in reducing the probability of a Type I error.

\section{RESULTS}

The frequencies of medical staff's demographic variables in this medical center are summarized in Table 2. A majority of medical staff are female (77.0\%) aged $21-50$ years old $(90.3 \%)$ who are not in change of supervisors/managers $(89.2 \%)$. More than $70 \%$ of staff do not report any event in the past 12 months. Nurses are the majority of the staff with $54.0 \%$, and $95.6 \%$ employees are full time. Experience in organization ranges from 1-2 years to 11-20 years (77.0\%), and experience in position ranges from 1-2 years to $11-20$ years $(78.1 \%)$. The majority of medical staff have college/university degrees $(79.4 \%)$ and very often to contact patients $(85.1 \%)$.

Table 2. Distributions of All Medical Staff in this Medical Center

\begin{tabular}{|c|c|c|}
\hline Demographic Variable & Frequency & Percentage \\
\hline $\begin{array}{l}\text { Gender } \\
\text { 1. Male } \\
\text { 2. Female }\end{array}$ & $\begin{array}{c}353 \\
1181\end{array}$ & $\begin{array}{l}23.0 \\
77.0\end{array}$ \\
\hline $\begin{array}{l}\text { Age } \\
\text { 1. Less than } 20 \text { years old } \\
\text { 2. } 21-30 \text { years old } \\
\text { 3. } 31-40 \text { years old } \\
\text { 4. } 41-50 \text { years old } \\
\text { 5. } 51-60 \text { years old } \\
\text { 6. } 61 \text { years old and above }\end{array}$ & $\begin{array}{c}4 \\
535 \\
488 \\
362 \\
128 \\
17\end{array}$ & $\begin{array}{l}0.3 \\
34.9 \\
31.8 \\
23.6 \\
8.3 \\
1.1\end{array}$ \\
\hline $\begin{array}{l}\text { Supervisor/Manager } \\
\text { 1. Yes } \\
\text { 2. No }\end{array}$ & $\begin{array}{c}165 \\
1369\end{array}$ & $\begin{array}{l}10.8 \\
89.2\end{array}$ \\
\hline $\begin{array}{l}\text { Respondents reporting events in the past } 12 \text { months } \\
\text { 1. No } \\
\text { 2. } 1-5 \\
\text { 3. } 6-10 \\
\text { 4. } 11-15 \\
\text { 5. More than } 16\end{array}$ & $\begin{array}{c}1092 \\
421 \\
13 \\
6 \\
2\end{array}$ & $\begin{array}{c}71.2 \\
27.4 \\
0.8 \\
0.4 \\
0.1\end{array}$ \\
\hline $\begin{array}{l}\text { Job Position } \\
\text { 1. Physician } \\
\text { 2. Nurse } \\
\text { 3. Technician } \\
\text { 4. Pharmacist } \\
\text { 5. Medical Administrator } \\
\text { 6. Respiratory Therapist } \\
\text { 7. Other }\end{array}$ & $\begin{array}{c}254 \\
828 \\
200 \\
63 \\
96 \\
49 \\
44\end{array}$ & $\begin{array}{l}16.6 \\
54.0 \\
13.0 \\
4.1 \\
6.3 \\
3.2 \\
2.9\end{array}$ \\
\hline $\begin{array}{l}\text { Job Status } \\
\text { 1. Full Time } \\
\text { 2. Contract } \\
\text { 3. Part Time } \\
\text { 4. Agency }\end{array}$ & $\begin{array}{c}1466 \\
56 \\
4 \\
8\end{array}$ & $\begin{array}{l}95.6 \\
3.7 \\
0.3 \\
0.5\end{array}$ \\
\hline $\begin{array}{l}\text { Experience in Organization } \\
\text { 1. Less than } 6 \text { months } \\
\text { 2. 6-11 months } \\
\text { 3. } 1-2 \text { years } \\
\text { 4. } 3-4 \text { years } \\
\text { 5. } 5-10 \text { years } \\
\text { 6. } 11-20 \text { years } \\
\text { 7. } 21 \text { years or more }\end{array}$ & $\begin{array}{c}119 \\
56 \\
245 \\
197 \\
293 \\
447 \\
177\end{array}$ & $\begin{array}{c}7.8 \\
3.7 \\
16.0 \\
12.8 \\
19.1 \\
29.1 \\
11.5\end{array}$ \\
\hline
\end{tabular}


Table 2. (continued) Distributions of All Medical Staff in this Medical Center

\begin{tabular}{lcc}
\multicolumn{1}{c}{ Demographic Variable } & Frequency & Percentage \\
\hline Experience in Position & & \\
1. Less than 6 months & 160 & 10.4 \\
2. 6-11 months & 59 & 3.8 \\
3. 1-2 years & 273 & 17.8 \\
4. 3-4 years & 206 & 13.4 \\
5. 5-10 years & 312 & 20.3 \\
6. 11-20 years & 406 & 26.5 \\
7. 21 years or more & 118 & 7.7 \\
Education & & \\
1. Junior High School or less & 3 & 0.2 \\
2. Senior High School & 18 & 1.2 \\
3. College/University & 1218 & 79.4 \\
4. Graduate School or more & 295 & 19.2 \\
Direct Patient Contact & & \\
1. No & 81 & 5.3 \\
2. Rare & 148 & 9.6 \\
3. Very Often & 1305 & 85.1 \\
\hline
\end{tabular}

Independent sample $t$ test is applied to test if medical staff perceive EE statistically different in gender as shown in Table 3. In addition, mean differences for supervisor/manager are examined in Table 4. From Table 3, female employees have higher burnout than male employees in these nine questions. Medical staff who are not supervisors/managers have significantly higher burnout than those who are not supervisors/managers in eight out of nine questions.

Table 5. shows age is a critical variable to influence emotional exhaustion. In general, medical staff whose ages are 21-30, 31-40, and 41-50 years old perceive statistically higher burnout than those whose ages are 51-60 and 61 years old and above. Medical staff who report 1-5 events have a higher degree of burnout than those who do not report any event in the past 12 months in four of nine questions as shown in Table 6. Table 7. summarizes that nurses might perceive the highest burnout in job status.

Job status is not an important variable to affect emotional exhaustion depicted in Table 8. Employees having different experience in an organization perceive significantly higher burnout in eight of nine questions in Table 9. In general, medical staff whose experiences are 3 to 4 and 5 to 10 years in an organization tend to have significantly higher burnout than those whose experiences are 21 years or more. In addition to experience in organization, experience in position plays an important role to influence emotional exhaustion in Table 10. Generally speaking, employees who have 3 to 4 and 5 to 10 years in position have statistically higher burnout than those who have 21 years or more in position. Moreover, education is an essential demographic variable to affect emotional exhaustion because eight of nine questions have p-values less than 0.05 in Table 11. That is, medical staff who have college-university degrees have statistically higher burnout than those who have senior high school or graduate school or more. Finally, Table 12 shows direct patient contact is also an important variable to influence emotional exhaustion. That is, employees who contact patients very often have a higher degree of burnout than those who has either no or rare contacts.

Table 3. Mean Differences in Gender

\begin{tabular}{cccc}
\hline Item & T & Sig. & Post Hoc Analysis \\
\hline 1. & -2.439 & .015 & Female $>$ Male \\
2. & -4.145 & $<.001$ & Female $>$ Male \\
3. & -3.613 & $<.001$ & Female $>$ Male \\
4. & -3.274 & .001 & Female $>$ Male \\
5. & -3.834 & $<.001$ & Female $>$ Male \\
6. & -5.069 & $<.001$ & Female $>$ Male \\
7. & -4.252 & $<.001$ & Female $>$ Male \\
8. & -3.341 & .001 & Female $>$ Male \\
9. & -2.889 & .004 & Female $>$ Male \\
\hline
\end{tabular}


Table 4. Mean Differences in Supervisor/Manager

\begin{tabular}{cccc}
\hline Item & T & Sig. & Post Hoc Analysis \\
\hline 1. & -5.165 & $<.001$ & No $>$ Yes \\
2. & -4.277 & $<.001$ & No $>$ Yes \\
3. & -4.690 & $<.001$ & No $>$ Yes \\
4. & -1.642 & .102 & \\
5. & -4.366 & $<.001$ & No $>$ Yes \\
6. & -4.471 & $<.001$ & No $>$ Yes \\
7. & -6.611 & $<.001$ & No $>$ Yes \\
8. & -5.489 & $<.001$ & No $>$ Yes \\
9. & -5.740 & $<.001$ & No $>$ Yes \\
\hline
\end{tabular}

Table 5. ANOVA Results in Age

\begin{tabular}{cccc}
\hline Item & F & Sig. & Post Hoc Analysis \\
\hline 1. & 11.530 & $<.001$ & $2>5 ; 2>6 ; 3>5 ; 3>6 ; 4>5 ; 4>6$ \\
2. & 10.682 & $<.001$ & $2>5 ; 2>6 ; 3>5 ; 3>6 ; 4>5 ; 4>6$ \\
3. & 11.083 & $<.001$ & $2>5 ; 2>6 ; 3>5 ; 3>6 ; 4>5 ; 4>6$ \\
4. & 4.360 & .001 & $2>6 ; 3>6 ; 4>6 ; 5>6$ \\
5. & 9.636 & $<.001$ & $2>5 ; 2>6 ; 3>5 ; 3>6 ; 4>5 ; 4>6$ \\
6. & 10.761 & $<.001$ & $2>5 ; 2>6 ; 3>5 ; 3>6 ; 4>5 ; 4>6$ \\
7. & 18.789 & $<.001$ & $2>4 ; 2>5 ; 2>6 ; 3>4 ; 3>5 ; 3>6 ; 4>5 ; 4>6$ \\
8. & 9.204 & $<.001$ & $2>5 ; 2>6 ; 3>5 ; 3>6 ; 4>5 ; 4>6$ \\
9. & 9.123 & $<.001$ & $2>5 ; 2>6 ; 3>5 ; 3>6 ; 4>5 ; 4>6$ \\
\hline
\end{tabular}

Table 6. ANOVA Results in Respondents Reporting Events in the Past 12 Months

\begin{tabular}{cccc}
\hline Item & F & Sig. & Post Hoc Analysis \\
\hline 1. & 1.176 & .319 & \\
2. & 3.553 & .007 & $2>1$ \\
3. & 1.872 & .113 & \\
4. & 3.271 & .011 & None \\
5. & 3.449 & .008 & $2>1$ \\
6. & 4.248 & .002 & $2>1$ \\
7. & 3.740 & .005 & $2>1$ \\
8. & 0.811 & .518 & \\
9. & 1.293 & .271 & \\
\hline
\end{tabular}

Table 7. ANOVA Results in Job Position

\begin{tabular}{cccc}
\hline Item & F & Sig. & Post Hoc Analysis \\
\hline 1. & 4.226 & $<.001$ & $2>1$ \\
2. & 8.892 & $<.001$ & $2>1 ; 2>3 ; 2>4$ \\
3. & 5.050 & $<.001$ & $2>1$ \\
4. & 6.085 & $<.001$ & $2>1 ; 7>1 ; 7>4$ \\
5. & 7.870 & $<.001$ & $2>1 ; 2>3 ; 2>4$ \\
6. & 11.909 & $<.001$ & $2>1 ; 2>3 ; 2>4 ; 2>5$ \\
7. & 11.476 & $<.001$ & $2>1 ; 2>3 ; 2>4 ; 2>5$ \\
8. & 5.465 & $<.001$ & $2>1$ \\
9. & 5.657 & $<.001$ & $2>1$ \\
\hline
\end{tabular}


Table 8. ANOVA Results in Job Status

\begin{tabular}{cccc}
\hline Item & F & Sig. & Post Hoc Analysis \\
\hline 1. & 0.809 & .489 & \\
2. & 0.845 & .469 & \\
3. & 0.760 & .517 & \\
4. & 2.405 & .066 & \\
5. & 0.636 & .592 & \\
6. & 1.110 & .344 & \\
7. & 0.377 & .770 & \\
8. & 0.260 & .854 & \\
9. & 0.024 & .995 & \\
\hline
\end{tabular}

Table 9. ANOVA Results in Experience in Organization

\begin{tabular}{cccc}
\hline Item & F & Sig. & Post Hoc Analysis \\
\hline 1. & 4.049 & $<.001$ & $4>7 ; 5>7 ; 6>7$ \\
2. & 1.801 & .095 & \\
3. & 2.153 & .045 & $4>7$ \\
4. & 3.593 & .002 & $6>1 ; 7>1$ \\
5. & 2.210 & .040 & None \\
6. & 2.018 & .060 & \\
7. & 5.817 & $<.001$ & $1>7 ; 3>7 ; 4>7 ; 5>7 ; 6>7$ \\
8. & 4.125 & $<.001$ & $4>2 ; 4>7 ; 6>7$ \\
9. & 4.524 & $<.001$ & $3>7 ; 4>7 ; 5>7 ; 6>7$ \\
\hline
\end{tabular}

Table 10. ANOVA Results in Experience in Position

\begin{tabular}{cccc}
\hline Item & F & Sig. & Post Hoc Analysis \\
\hline 1. & 4.446 & $<.001$ & $4>7 ; 5>7 ; 6>7$ \\
2. & 2.362 & .028 & $4>7$ \\
3. & 3.338 & .003 & $1>7 ; 3>7 ; 4>7 ; 6>7$ \\
4. & 2.150 & .045 & None \\
5. & 2.178 & .043 & $5>7$ \\
6. & 3.201 & .004 & $3>7 ; 4>7 ; 5>7$ \\
7. & 5.269 & $<.001$ & $1>7 ; 3>7 ; 4>7 ; 5>7 ; 6>7$ \\
8. & 2.833 & .010 & $4>7$ \\
9. & 2.150 & .045 & $4>7$ \\
\hline
\end{tabular}

Table 11. ANOVA Results in Education

\begin{tabular}{cccc}
\hline Item & F & Sig. & Post Hoc Analysis \\
\hline 1. & 7.521 & $<.001$ & $3>2 ; 3>4$ \\
2. & 10.550 & $<.001$ & $3>2 ; 3>4$ \\
3. & 9.796 & $<.001$ & $3>2 ; 3>4$ \\
4. & 0.351 & .788 & \\
5. & 8.151 & $<.001$ & $3>2 ; 3>4$ \\
6. & 6.127 & $<.001$ & $3>4$ \\
7. & 11.611 & $<.001$ & $3>4$ \\
8. & 10.358 & $<.001$ & $3>2 ; 3>4$ \\
9. & 11.364 & $<.001$ & $3>2 ; 3>4$ \\
\hline
\end{tabular}


Table 12. ANOVA Results in Direct Patient Contact

\begin{tabular}{cccc}
\hline Item & F & Sig. & Post Hoc Analysis \\
\hline 1. & 13.601 & $<.001$ & $3>2$ \\
2. & 10.896 & $<.001$ & $3>1 ; 3>2$ \\
3. & 3.467 & .031 & None \\
4. & 8.021 & $<.001$ & $3>1 ; 3>2$ \\
5. & 11.381 & $<.001$ & $3>1 ; 3>2$ \\
6. & 18.706 & $<.001$ & $3>1 ; 3>2$ \\
7. & 19.068 & $<.001$ & $3>1 ; 3>2$ \\
8. & 12.662 & $<.001$ & $3>2$ \\
9. & 6.457 & .002 & $3>2$ \\
\hline
\end{tabular}

Based on the findings, gender, age, job position, experience in position, and direct patient contact are most essential variables to affect all questions in EE dimension. Supervisor/manager, education, and experience in organization are also important variables to affect at least seven out of nine questions. In contrast, respondents reporting events in the past 12 months and job status are least important demographic variables in this medical center.

\section{DISCUSSION}

Rare studies have been found to examine the relationship between medical staff's demographic variables and emotional exhaustion. In 2016, Lee, Huang, Weng, et al., (2016) identified five variables, including supervisor/manager, job position, age, experience in organization, and experience in position, are critically important to affect emotional exhaustion for physicians and nurses from a regional teaching hospital in Taiwan. However, these five critical variables simply influence three to four questions in EE dimension. On the other hand, this study shows that eight demographic variables except for respondents reporting events in the past 12 months and job status can be viewed as essential variables that affect seven to nine questions.

The possible reasons that medical staff with these eight critical demographic variables perceive emotional exhaustion statistically different are that working in a medical center might be more stressful than working in a regional teaching hospital in Taiwan. In reality, employees who work in a medical center might have higher workloads in Taiwan. Therefore, hospital management in this medical center needs to reduce employees' fatigue. Lee, Huang, Huang, et al., (2016) recommended a hospital can monitor medical staff's burnout first and then try to reduce their burden regularly.

In practice, the medical center can use different types of approaches to help medical staff improve stress, pain, and illness, such as mindfulness-based stress reduction (MBSR) programs, "positivity currency", "appreciative inquiry" groups (Lee, Huang, Huang, et al., 2016), cognitive behavioral therapy (Gustafsson et al., 2017), rational emotive behavior counseling (Kim \& Yoon, 2018), solution focused brief counseling (Ateş, 2016), and many other therapies. When high burnout employees are found, hospital management can initiate the above approaches to reduce their resilience.

Each medical center in Taiwan is responsible to provide necessary health services to the best of its ability and to ensure the reasonable safety within the facility. That is, each medical center has to put many safety measures in place to reduce falls, infections, and medication errors. Besides, patients and hospitals should work together to lower the risk of accidents and improve the safety for all involved. Obviously, the degree of burnout for each medical staff should be closely monitored in practice in order to reduce medical errors in hospitals. This study provides a framework to assess the medical staff's burnout in terms of emotional exhaustion from a medical center in Taiwan by independent sample $t$ test and analysis of variance. This framework can be further applied to other hospitals to evaluate the medical staff's fatigue, particularly those who are in a higher degree of burnout. In doing so, hospitals can relentlessly enhance their patient safety and healthcare quality to their patients. 


\section{CONCLUSION}

A case study of analyzing EE from a medical center is presented. Except for respondents reporting events in the past 12 months and job status, the other eight demographic variables are critical variables to influence emotional exhaustion in this medical center. The post hoc analyses also indicate that medical staff with some characteristics have higher burnout. For instance, female employees and employees who are not supervisors/managers have a higher degree of fatigue. In addition, staff with ages of 21-30, 31-40, and 41-50 perceive higher burnout. Moreover, nurses are more stressful than the others. The detailed post hoc analyses enable hospital management to identify employees with high burnout. Later, hospital management can initiate some activities to improve their resilience through different types of recommendations depicted earlier.

\section{REFERENCES}

Ateş, B. (2016). Effect of solution focused group counseling for high school students in order to struggle with school burnout. Journal of Education and Training Studies, 4(4), 27-34.

Chi, C.-Y., Huang, C.-H., Lee, Y.-C., \& Wu, H.-H. (2019). Critical demographic variables on affecting patient safety culture from medical staffs' viewpoints. Engineering Letters, 27(2), 328-335.

Cimiotti, J. P., Aiken, L. H., Sloane, D. M., \& Wu, E. S. (2012). Nurse staffing, burnout, and health care-associated infection. American Journal of Infection Control, 40(6), 486-490.

Gustafsson, H., DeFreese, J. D., \& Madigan, D. J. (2017). Athlete burnout: Review and recommendations. Current Opinion in Psychology, 16, 109-113.

Huang, C.-H., Wu, H.-H., \& Lee, Y.-C. (2018). The perceptions of patient safety culture: A difference between physicians and nurses in Taiwan. Applied Nursing Research, 40, 39-44.

Huang, C.-H., Wu, H.-H., Lee, Y.-C., \& Li, L. (2019). What Role Does Patient Gratitude Play in the Relationship Between Relationship Quality and Patient Loyalty? Inquiry: The Journal of Health Care Organization, Provision, and Financing, 56, 0046958019868324.

Kim, H.-L., \& Yoon, S.-H. (2018). Effects of group rational emotive behavior therapy on the nurses' job stress, burnout, job satisfaction, organizational commitment and turnover intention. Journal of Korean Academy of Nursing, 48(4), 432-442.

Lee, Y.-C., Huang, C.-H., Weng, S.-J., Hsieh, W.-L., \& Wu, H.-H. (2016). Analyzing emotional exhaustion from viewpoints of physicians and nurses-A case of a regional teaching hospital. TEM Journal, 5(2), 231-235.

Lee, Y.-C., Huang, S.-C., Huang, C.-H., \& Wu, H.-H. (2016). A new approach to identify high burnout medical staffs by kernel k-means cluster analysis in a regional teaching hospital in Taiwan. Inquiry: The Journal of Health Care Organization, Provision, and Financing, 53, 0046958016679306.

Lee, Y.-C., Shieh, J.-I., Huang, C.-H., Wang, C. Y., \& Wu, H.-H. (2017). Analyzing patient safety culture from viewpoints of physicians and nurses-A case of a regional teaching hospital in Taiwan. The Journal for Healthcare Quality (JHQ), 39(5), 294-306.

Maslach, C., Leiter, M. P., \& Fink, G. (2016). Stress: Concepts, Cognition, Emotion, and Behavior. Handbook of Stress Series, Volume 1, Pages 351-357.

Maslach, C., Schaufeli, W. B., \& Leiter, M. P. (2001). Job burnout. Annual Review of Psychology, 52(1), 397-422.

McHugh, M. L. (2011). Multiple comparison analysis testing in ANOVA. Biochemia Medica, 21(3), 203-209.

Shanafelt, T. D. (2009). Enhancing meaning in work: a prescription for preventing physician burnout and promoting patient-centered care. The Journal of American Medical Association, 302(12), 1338-1340.

Shanafelt, T. D., Balch, C. M., Bechamps, G., Russell, T., Dyrbye, L., Satele, D., Collicott, P., Novotny, P. J., Sloan, J., \& Freischlag, J. (2010). Burnout and medical errors among American surgeons. Annals of Surgery, 251(6), 995-1000.

Shanafelt, T. D., Dyrbye, L. N., \& West, C. P. (2017). Addressing physician burnout: The way forward. JAMA, 317(9), 901-902.

West, C. P., Dyrbye, L. N., Erwin, P. J., \& Shanafelt, T. D. (2016). Interventions to prevent and reduce physician burnout: A systematic review and meta-analysis. The Lancet, 388(10057), 2272-2281.

Wu, H.-H., Chou, C.Y., Dai, H., \& Lee, Y.-C. (2018). The perceptions of physicians and nurses regarding the establishment of patient safety in a regional teaching hospital in Taiwan. Iranian Journal of Public Health, $47(6), 852-860$. 